\title{
KUALITAS MIKROBIOLOGI ES BATU KRISTAL DAN HYGIENE SANITASI SEPANJANG RANTAI DISTRIBUSI DI SURABAYA
}

\author{
Nur Zumairotul Muna, AT. Diana Nerawati, Rachmaniyah
}

\begin{abstract}
Crystal ice cube consumed by people is distributed through distribution chain from factories, agents, and ice traders in Surabaya. Each distribution chain posses risk of contamination to the quality of the ice, one of which is microbiological contamination that cause health problems to consumers.

This is descriptive study aimed to obtain microbiological quality of crystal ice cube and hygiene sanitation throughout distribution chain in Surabaya. Sampling and observations were conducted sequentially in the same day, in different time and with 3 time repetition for 3 days in a row. Data were analyzed descriptively.

The result showed that the ice crystals did not contain E. coli yet contained MPN Coliform. The rate of MPN Coliform on ice at factory was 10 colonies / 100 cC sample, at agent was 12-15 colonies / 100 cC sample, and at merchant were 15-43 colonies / 100 cc sample. Hygiene sanitation affecting MPN Coliform in crystal ice are non standard raw materials, production process, transportation, and the handlers.

In conclusion, microbiological quality of crystal ice cube along the distribution chain in Surabaya with E. coli parameter did not meet standard. Health Department needs to conduct surveillance on a regular basis. Factory of ice cube needs to make Standard Operating Procedures. Agents and traders need to improve hygiene sanitation of conveyance, transport personnel, equipment, and handlers.
\end{abstract}

Keywords $\quad$ : Ice Cube Crystals, Chain Distribution, Hygiene Sanitation, MPN Coliform, E. coli

\section{PENDAHULUAN}

Es batu adalah massa padat hasil pembekuan air minum (SNI, 1995). Es batu banyak digunakan untuk konsumsi langsung yaitu dengan cara memasukkan es batu ke dalam minuman atau menjadikannya sebagai bahan pembuatan es blender. (Eliyanti, 2014)

Jika es batu ditambahkan ke dalam minuman, maka standar kualitas es batu harus sesuai dengan SNI 01-3839-1995 tentang es batu dan standar air minum yang telah diatur oleh Permenkes RI Nomor 492/MENKES/PER/2010 tentang persyaratan kualitas air minum, bahwa kadar maksimum Escherichia coli dan total Coliform pada air minum masing-masing adalah 0 jumlah per 100 $\mathrm{ml}$ sampel. Berdasarkan hasil survey pendahuluan di salah satu pabrik penghasil es batu kristal di Surabaya didapatkan bahwa pabrik tersebut mampu menghasilkan $18-19$ ton es batu kristal setiap hari dan mendistribusikannya kepada 3 agen besar yang menyebar di wilayah Gresik dan Surabaya. Terdapat beberapa masalah sanitasi di pabrik tersebut, diantaranya tidak terdapat fasilitas cuci tangan untuk karyawan, karyawan yang bekerja dibagian produksi tidak memakai penutup kepala, sarung tangan dan tidak mencuci tangan sebelum masuk kerja, hasil produk es batu kristal yang telah dikemas diangkut ke dalam mobil boks dengan cara diseret di lantai. Dari beberapa masalah di atas memungkinkan terjadinya kontaminasi pada produk es batu. Jika tingkat kontaminasi bakteri Coliform tinggi akan tinggi pula risiko kehadiran bakteri-bakteri patogen lain yang biasa hidup dalam kotoran manusia dan hewan. Salah satu contoh bakteri patogen yang kemungkinan terdapat dalam air terkontaminasi kotoran manusia atau hewan berdarah panas ialah bakteri Escherichia coli, yaitu mikroba penyebab gejala diare, demam, kram perut, dan muntahmuntah (Entjang, 2003).

Tujuan dari penelitian ini adalah mengetahui kualitas mikrobiologi es batu kristal dan hygiene sanitasi sepanjang rantai distribusi di Surabaya.

\section{METODE PENELITIAN}

Jenis penelitian ini adalah deskriptif. Teknik pengambilan sampel menggunakan purposive sampling yaitu pengambilan sampel dilakukan di pabrik (bahan baku dan es batu kristal), es batu kristal di agen dan 5 (lima) pedagang dengan replikasi sebanyak 3 kali, sehingga besar sampel untuk penelitian ini adalah 27 sampel. Sedangkan untuk observasi hygiene sanitasi dalam penelitian ini pada 7 titik lokasi yang terdiri dari pabrik, agen, dan 5 pedagang es batu kristal. Pengambilan sampel dan observasi hygiene sanitasi pada masing- 
masing rantai distribusi (pabrik, agen, pedagang es) dilakukan secara berurutan pada hari yang sama, namun berbeda waktu dengan pengulangan selama 3 hari berturut-turut. Data dianalisis secara deskriptif dengan membandingkan hasil pemeriksaan kualitas mikrobiologi es batu (MPN Coliform dan Escherichia coli) dengan Permenkes RI Nomor 492/MENKES/PER/2010 yaitu kualitas mikrobiologi es batu memenuhi syarat jika MPN Coliform dan Escherichia coli masing-masing 0 jumlah per $100 \mathrm{ml}$ sampel dan menggambarkan hasil pengamatan terhadap hygiene sanitasi di tingkat distribusi pabrik berdasarkan Peraturan Menteri Perindustrian RI Nomor: 75/MIND/PER/7/2010 tentang Pedoman Cara Produksi Pangan Olahan yang Baik (Good Manufacturing Practices); di tingkat distribusi agen berdasarkan (Ketentuan hygiene santasi pada aspek pengangkutan dan penyimpanan produk pangan, Departemen Kesehatan, 2002); dan di tingkat distribusi pedagang es berdasarkan Keputusan Menteri Kesehatan RI Nomor: 1098/MENKES/SK/VII/2003 tentang Persyaratan Hygiene Sanitasi Rumah Makan dan Restoran dan Keputusan Menteri Kesehatan RI Nomor: 942/MENKES/SK/VII/2003 tentang Pedoman Persyaratan Hygiene Sanitasi Makanan Jajanan.

\section{HASIL DAN PEMBAHASAN}

\section{A. Identifikasi MPN Coliform dan Bakteri Escherichia coli pada Es Batu Kristal} Hasil pemeriksaan kualitas mikrobiologi pada bahan baku yaitu air olahan yang berasal dari air sumur di pabrik dapat dilihat pada tabel 1 .

Tabel 1

Hasil Pemeriksaan E. coli dan MPN Coliform pada Air Sumur dan Air Olahan dari Pabrik Tahun 2016

Parameter/ Pemeriksaan ke- Kualitas Air Sumur (kol/100 ml Kualitas Air Olahan (kol/100

\begin{tabular}{cccc}
\multicolumn{2}{c}{ Parameter/ Pemeriksaan ke- } & sampel) & ml sampel $)$ \\
\hline & E. coli & & 0 \\
\hline 1 & 0 & 0 \\
\hline Range & 3 & 0 & 0 \\
\hline & MPN Coliform & 0 & 0 \\
\hline & 1 & & 39 \\
\hline 2 & 460 & 39 \\
\hline Range & 3 & 460 & 24 \\
\hline Keterangan & 460 & $24-39$ \\
\hline
\end{tabular}

Keterangan :

Standar Permenkes RI Nomor 492/MENKES/PER/2010

E. coli $\quad=0$ koloni $/ 100 \mathrm{ml}$ sampel

MPN Coliform $=0$ koloni $/ 100 \mathrm{ml}$ sampel

Hasil pemeriksaan diketahui bahwa kandungan $E$. coli pada air sumur dan air olahan 0 koloni / $100 \mathrm{ml}$ sampel atau negatif yang berarti memenuhi syarat, Sedangkan kandungan MPN Coliform air sumur sangat tinggi sebesar 460 koloni/100 ml sampel. Ini dimungkinkan sumur memiliki jarak dekat sekitar 2 meter dengan Saluran Pembuangan Air Limbah (SPAL) produksi dan kamar mandi karyawan. Cemaran Coliform ini diduga bersumber dari perembesan air SPAL dengan indikator air yang sudah keruh dan berbau. Menurut Entjang (2000), saluran pembuangan air limbah (SPAL) dari sekitar sumur dibuat

tembok yang kedap air dan panjangnya sekurang-kurangnya 10 meter, sedangkan pada sumur gali yang dilengkapi pompa, pada dasarnya pembuatannya sama dengan sumur gali tanpa pompa. Oleh karena itu pabrik harus melakukan pengolahan pada air sumur sebagai berikut, filtrasi menggunakan pasir resin dan karbon aktif kemudian dilewatkan membran Reverse Osmosis (RO) yang dilakukan sebanyak dua kali pengulangan setelah itu air dilewatkan melalui sinar UV, sehingga diperoleh air olahan yang siap untuk digunakan untuk pembuatan es batu kristal. Hasil pemeriksaan air olahan menunjukkan parameter MPN Coliform positif sebesar 39 koloni/100 ml sampel. Ini menunjukkan bahwa pengolahan air mampu menurunkan kandungan MPN Coliform akan tetapi belum efektif hal ini dimungkinkan kemampuan sinar UV yang dipakai tidak sesuai dengan kapasitas pompa air. Volume air olahan yang masuk pada sinar UV lebih besar dibandingkan dengan kemampuan sinar UV dalam membunuh bakteri. Namun tidak ada standarisasi oleh pabrik bahwa setiap satuan pengolahan (satu kali proses) dilengkapi 
petunjuk yang menyebutkan jumlah seluruh bahan baku air yang digunakan dalam satu kali proses pengolahan. Pabrik hanya mementingkan jumlah produk es batu kristal yang dihasilkan. Pada hari pertama dan kedua pabrik es batu kristal menghasilkan 19 ton, sedangkan pada hari ketiga pengambilan sampel, pabrik menghasilkan 18 ton es batu kristal. Pada hari ketiga pengambilan sampel air olahan, kandungan MPN Coliform menjadi 24 koloni/100 ml sampel. Volume air yang masuk kedalam sinar UV lebih kecil dibandingkan 2 hari sebelumnya sehingga kandungan MPN Coliform menurun karena sinar UV lebih efektif dalam membunuh bakteri.

Sedangkan hasil pemeriksaan es batu kristal dari Pabrik, Agen, dan Pedagang es batu kristal dapat dilihat pada tabel 2.

Tabel 2

Hasil Pemeriksaan E. Coli dan MPN Coliform pada Es Batu Kristal Sepanjang Rantai Distribusi di Surabaya Tahun 2016

\begin{tabular}{|c|c|c|c|}
\hline \multirow[b]{2}{*}{ No. } & \multirow[b]{2}{*}{ Rantai Distribusi } & \multicolumn{2}{|c|}{ Kualitas Mikrobiologi } \\
\hline & & E. coli (kol/100 ml sampel) & $\begin{array}{l}\text { MPN Coliform (kol/100 ml } \\
\text { sampel) }\end{array}$ \\
\hline 1. & Pabrik & 0 & 10 \\
\hline 2. & Agen & 0 & $12-15$ \\
\hline 3. & Pedagang A & 0 & $15-17$ \\
\hline 4. & Pedagang B & 0 & $15-17$ \\
\hline 5. & Pedagang $\mathrm{C}$ & 0 & $17-21$ \\
\hline 6. & Pedagang D & 0 & $21-24$ \\
\hline 7. & Pedagang $\mathrm{E}$ & 0 & $39-43$ \\
\hline
\end{tabular}

Hasil pemeriksaan kualitas mikrobiologi es batu kristal parameter E. coli 0 koloni $/ 100 \mathrm{ml}$ sampel yang berarti memenuhi syarat. Sedangkan MPN Coliform tidak memenuhi syarat, diketahui bahwa terjadi peningkatan MPN Coliform pada setiap rantai distribusinya. Es batu kristal dari pabrik mengandung MPN Coliform sebesar $10 \mathrm{koloni} / 100 \mathrm{ml}$ sampel, dari pabrik menuju agen kandungan MPN coliform meningkat menjadi 12 koloni/100 ml sampel. Dari agen menuju ke pedagang meningkat menjadi 15 - 17 koloni/100 ml sampel. Dan peningkatan paling tinggi terjadi pada es batu kristal di pedagang E pasar atom sebesar 39 43 koloni/100 ml sampel.

Dari perbandingan tersebut dapat dilihat bahwa terdapat perbedaan mutu mikrobiologi es batu pada tingkat jalur distribusi yang berbeda. Mutu mikrobiologi es batu dari pabrik lebih baik dari es batu yang diperoleh dari agen es batu, dan mutu mikrobiologi es batu dari agen es batu lebih baik dari pedagang es.

\section{B. Hygiene Sanitasi Sepanjang Rantai Distribusi Es Batu Kristal di Surabaya}

1. Pabrik Es Batu Kristal

Penilaian dilakukan mengacu pada Peraturan Menteri Perindustrian RI Nomor: 75/MIND/PER/7/2010 tentang Pedoman Cara Produksi Pangan Olahan yang Baik (Good Manufacturing Practices). Rekapitulasi hasil penilaian hygiene sanitasi Pabrik dapat dilihat pada tabel 3.

Tabel 3

Hasil Penilaian Hygiene Sanitasi di Pabrik Tahun 2016

\begin{tabular}{|c|c|c|c|}
\hline No. & Variabel & Persentase (\%) & Kategori \\
\hline 1. & Lokasi \& Bangunan & 90 & $B$ \\
\hline 2. & Bahan Baku Produksi & 0 & $\mathrm{~K}$ \\
\hline 3. & Mesin / Peralatan Produksi & 100 & $B$ \\
\hline 4. & Karyawan / Penjamah & 60 & $\mathrm{C}$ \\
\hline 5. & Pengemas Produk & 30 & $\mathrm{~K}$ \\
\hline 6. & Pengawasan Proses & 51,82 & $\mathrm{C}$ \\
\hline 7. & Pengangkutan & 40 & $\mathrm{C}$ \\
\hline Jumlah & & 55,65 & C \\
\hline
\end{tabular}


Hasil penilaian hygiene sanitasi di Pabrik adalah kategori cukup baik $(55,65 \%)$.

Bahan baku produksi mendapatkan persentase 0\% dikarenakan bahan baku air olahan masih mengandung MPN Coliform sehingga tidak memenuhi syarat.

Karyawan / penjamah mendapatkan persentase $60 \%$ (kategori cukup), kondisinya karyawan tidak memakai APD (Alat Pelindung Diri) lengkap seperti penutup kepala/ topi dan sarung tangan dan hanya memakai seragam dan sepatu karet. Penjamah juga hanya mencuci tangan saat tiba di tempat kerja. Menurut Depkes RI (2004) salah satu upaya pengamanan makanan yaitu rambut ditutup dengan penutup rambut yang menutup bagian depan sehingga tidak terurai. Dan kebersihan tangan sangat penting bagi setiap orang terutama bagi penjamah makanan / minuman. Untuk mengurangi resiko cemaran es batu kristal dari karyawan maka perlu dilakukan kebiasaan mencuci tangan karena sangat membantu dalam mencegah penularan bakteri dari tangan kepada produk es batu kristal.

Sedangkan pengemas produk mendapatkan persentase 30\% (kategori kurang). Pengemas yang dipakai untuk es batu kristal adalah plastik. Plastik terbuat dari bahan tidak larut terhadap es batu kristal, plastik juga disimpan dan ditangani secara hygienis. Namun plastik tidak dapat melindungi dan mempertahankan mutu es batu kristal, tidak tahan terhadap perlakuan selama pengangkutan dan peredaran, bahan pengemas, karena saat pengangkutan plastik berisi es batu kristal dilubangi sehingga plastik sudah tidak memenuhi syarat pengemas produk.

Pada pengawasan proses mendapatkan persentase $51,82 \%$ (kategori cukup), ini dikarenakan setiap produk tidak dilengkapi petunjuk yang menyebutkan jenis dan jumlah bahan yang digunakan, tahap proses produksi secara rinci, langkah-langkah yang diperhatikan selama proses produksi, dan jumlah produk yang diperoleh untuk satu kali produksi. Setiap satuan pengolahan (satu kali proses) tidak menyebutkan tanggal pembuatan dan kode produksi, jenis dan jumlah bahan yang digunakan dalam satu kali proses pengolahan, dan jumlah produksi yang diolah.

Pada pengangkutan mendapatkan persentase $40 \%$. Wadah dan alat angkut yang digunakan adalah mobil boks. Pada saat pengangkutan, es batu yang dikemas dalam plastik dimasukkan ke dalam truk pengangkut dengan cara diseret dilantai yang sebelumnya dibasahi dengan air. Kemudian tenaga pengangkut memindahkan es batu dari lantai kedalam mobil boks. Ada tenaga pengangkut yang naik ke dalam mobil boks menggunakan sepatu boot yang kotor dan plastik dilubangi oleh tenaga pengangkut menggunakan bolpoin untuk menghindari pencairan es yang lebih cepat, sehingga terjadi kontaminasi antara alat angkut dan es batu kristal. Menurut Depkes RI (2002) Cara pengangkutan makanan / minuman harus benar dan tidak terjadi pengotoran selama diangkut dan pengangkutan makanan / minuman dari jenis makanan / minuman yang tidak berkarat atau yang langsung dapat dimakan harus ditempatkan dalam suatu wadah yang tertutup.

Selain itu mobil boks tidak dapat mempertahankan suhu, sehingga dimungkinkan terjadinya pencairan pada es batu kristal. Menurut Jay (2005) Hal yang sangat penting pada pembekuan adalah kelangsungan hidup mikroorganisme pada proses pencairan / thawing. Pembekuan dan pencairan berulangulang akan menghancurkan bakteri dengan mengganggu membran sel. Namun semakin cepat mencair, semakin besar jumlah bakteri yang selamat / bertahan hidup. Menurut Kepmenkes (2003) penyimpanan beku (frozen) yaitu suhu penyimpanan minimal $-10^{\circ} \mathrm{C}$ sampai $50^{\circ} \mathrm{C}$ atau lebih rendah dari itu. Sehingga pengangkutan menjadi salah satu faktor yang mempengaruhi terhadap bertambahnya MPN Coliform. Oleh karena itu dianjurkan menggunakan mobil boks yang memiliki pengatur suhu minimal $-10^{\circ} \mathrm{C}$, selain mencegah pencairan es batu kristal juga membuat tenaga pengangkut tidak perlu melubangi wadah / plastik yang dapat mencemari es batu kristal dengan lingkungan luar.

2. Agen Es Batu Kristal Pasar Atom Surabaya Penilaian dilakukan mengacu pada (Ketentuan hygiene santasi pada aspek pengangkutan dan penyimpanan produk pangan Departemen Kesehatan, 2002). Hasil penilaian hygiene sanitasi di Agen Es Batu Kristal Pasar Atom Surabaya sebagai berikut:

Tabel 4

Hasil Penilaian Hygiene Sanitasi di Agen Es Batu Kristal Pasar Atom Surabaya Tahun 2016

\begin{tabular}{|c|c|c|c|}
\hline No. & Variabel & Persentase (\%) & Kategori \\
\hline 1. & Pengangkutan & 37,86 & $\mathrm{C}$ \\
\hline 2. & Penyimpanan & 100 & $B$ \\
\hline & Jumlah & 51,67 & $\mathrm{C}$ \\
\hline
\end{tabular}


Hasil penilaian hygiene sanitasi di Agen Es Batu Kristal Pasar Atom Surabaya mendapatkan hasil persentase skore $51,67 \%$ yang berarti kategori cukup baik.

Pengangkutan pada agen es batu kristal akan mempengaruhi kualitas es batu kristal pada tingkat distibusi selanjutnya yaitu pedagang es. Alat angkut di agen es berupa mobil boks. Mobil boks tidak dapat mempertahankan suhu dan kelembaban sehingga kurang memenuhi syarat. Tenaga pengangkut memindahkan es batu dari boks penyimpanan es batu kristal kedalam mobil boks. Ada tenaga pengangkut yang naik ke dalam mobil boks menggunakan sepatu boot yang kotor dan plastik es batu yang sudah berlubang memungkinkan kontaminasi antara alat angkut dan es batu kristal.

3. Pedagang Es Batu Kristal Pasar Atom Surabaya

Penilaian dilakukan mengacu pada Keputusan Menteri Kesehatan RI Nomor: 1098/MENKES/SK/VII/2003 tentang Persyaratan Hygiene Sanitasi Rumah Makan dan Restoran dan Keputusan Menteri Kesehatan RI Nomor: 942/MENKES/SK/VII/2003 tentang Pedoman Persyaratan Hygiene Sanitasi Makanan Jajanan. Hasil penilaian hygiene sanitasi di Pedagang es batu kristal Pasar Atom Surabaya dapat dilihat pada tabel 5.

Tabel 5

Hasil Penilaian Hygiene Sanitasi (HS) di Pedagang Es Batu Kristal Pasar Atom Surabaya Tahun 2016

\begin{tabular}{|c|c|c|c|c|c|c|}
\hline \multirow[t]{2}{*}{ No. } & \multirow[t]{2}{*}{ Variabel } & \multicolumn{4}{|c|}{ Skore (\%) } & \multirow[b]{2}{*}{$E$} \\
\hline & & A & $\mathrm{B}$ & $\mathrm{C}$ & $\mathrm{D}$ & \\
\hline 1. & Lokasi dan Bangunan & 100 & 100 & 85 & 85 & 100 \\
\hline 2. & Penanganan & 100 & 100 & 50 & 50 & 0 \\
\hline 3. & Peralatan & 40 & 40 & 40 & 40 & 30 \\
\hline 4. & Tenaga Kerja & 91,67 & 91,67 & 51,67 & 41,67 & 50 \\
\hline & Jumlah & 77,22 & 77,22 & 55,44 & 52,41 & 31,65 \\
\hline
\end{tabular}

Hasil penilaian pada pedagang A dan B memperoleh persentase $77,22 \%$ yang berarti baik. Pedagang $C$ dan $D$ mendapatkan kategori cukup baik dengan persentase berturut-turut $55,44 \%$ dan $52,41 \%$, dan pedagang $E$ memperoleh persentase $31,65 \%$ yang berarti kurang baik.

Dari agen Pasar Atom Surabaya es batu kristal didistribusikan ke pedagang minuman di Pasar Atom Surabaya yaitu Pedagang A, B, C, $D$, dan E. Sesuai tabel 2 hasil pemeriksaan sampel es batu kristal dari Pedagang A dan B dengan parameter $\mathrm{E}$. coli menunjukkan hasil negatif, namun parameter MPN Coliform positif sebesar 15 - 17 koloni/100 ml sampel. Terjadi peningkatan MPN Coliform pada es batu kristal dari agen Pasar Atom ke Pedagang A dan B. Ini dikarenakan peralatan / wadah es batu kristal cara pencucian kurang baik yaitu pada saat wadah selesai dicuci dilap menggunakan lap kain.

Kondisi peralatan yang sama juga terjadi pada pedagang $C$ dan $D$. Hasil pemeriksaan mikrobiologi MPN Coliform pada pedagang C sebesar 17 - 21 koloni/100 ml sampel sedangkan pada pedagang $D$ sebesar $21-24$ koloni/100 ml sampel. Terlihat pada kedua pedagang ini bahwa karyawan hanya mencuci tangan saat tiba di tempat kerja dan tidak memakai sarung tangan plastik saat menangani es batu kristal.
Sedangkan pada pedagang $\mathrm{E}$ hasil pemeriksaan MPN Coliform didapat paling tinggi yaitu 39 - 43 koloni/100 ml sampel. Kondisi pada pedagang $E$ terlihat penjamah tidak mencuci tangan, mempunyai kuku panjang dan termos yang dipakai jarang dicuci, dicuci hanya 3 hari sekali dan pengeringannya menggunakan lap kain.

Penanganan pada pedagang A dan B memperoleh persentase $100 \%$. Ini dikarenakan tenaga kerja memakai pakaian kerja dengan benar dan cara kerja yang bersih dengan selalu mencuci tangan saat akan menangani es batu kristal, pedagang A dan B saat mengambil es batu juga memakai sarung tangan. Pada pedagang $\mathrm{C}$ dan $\mathrm{D}$ memperoleh persentase $50 \%$. Ini dikarenakan tenaga kerja memakai pakaian kerja dengan benar namun cara kerja kurang bersih dengan hanya mencuci tangan saat sampai di tempat kerja dan tidak mencuci tangan saat akan menangani es batu kristal, pedagang $C$ dan $D$ jugga tidak memakai sarung tangan saat mengambil es batu kristal. Sedangkan pedagang $\mathrm{E}$ memperoleh persentase $0 \%$. Ini dikarenakan tenaga kerja tidak memakai pakaian kerja karena tidak memiliki seragam kerja dan cara kerja kurang bersih dengan tidak mencuci tangan saat akan menangani es batu kristal, pedagang $E$ jugga tidak memakai sarung tangan saat mengambil es batu kristal. 
Menurut Depkes (2006) prinsip penggunaan lap pada alat yang sudah dicuci bersih tidak diperbolehkan karena akan terjadi pencemaran sekunder (rekontaminasi). Toweling dapat digunakan dengan syarat bahwa towel yang digunakan harus steril serta sering diganti untuk sejumlah penggunaan atau menggunakan sekali pakai (single use). Menurut Kepmenkes (2003) Pengeringan peralatan harus memenuhi ketentuan: Peralatan yang sudah didesinfeksi harus ditiriskan pada rak-rak anti karat sampai kering sendiri dengan bantuan sinar matahari atau sinar buatan/mesin dan tidak boleh dilap dengan kain. Menurut Depkes (2004) kebiasaan mencuci tangan sangat membantu mencegah penularan bakteri dari tangan kepada makanan / minuman. Sehingga dimungkinkan terjadi kontaminasi antara wadah / termos saat wadah kontak langsung dengan es batu kristal dan kemungkinan kontaminasi juga berasal dari karyawan / penjamah sehingga kandungan MPN Coliform meningkat.

Tabel 6

Masalah peralatan dan karyawan / penjamah ini dapat menjadi resiko bertambahnya MPN Coliform pada es batu kristal, terbukti sampel es batu kristal dari agen mengalami kenaikan MPN Coliform setelah tiba di pedagang. Hal ini dapat dikurangi dengan cara meningkatkan sanitasi pada peralatan (termos) dengan memakai towel steril atau towel sekali pakai untuk mengeringkan peralatan, atau bisa dengan ditiriskan pada rakrak anti karat sampai kering sendiri dengan bantuan sinar matahari atau sinar buatan/mesin. Dan untuk karyawan bisa dengan mencuci tangan setiap akan menangani es batu kristal serta menggunakan sarung tangan pastik.

4. Hygiene Sanitasi Sepanjang Rantai Distribusi Es Batu Kristal

Dari hasil penilaian pada tabel 3, tabel 4, dan tabel 5 menunjukkan hasil akhir kondisi hygiene sanitasi sepanjang rantai distribusi (pabrik, agen dan pedagang) es batu kristal dapat dilihat pada tabel 6.

Rekapitulasi Hygiene Sanitasi Sepanjang Rantai Distribusi Es Batu Kristal di Surabaya Tahun 2016

No.

Rantai Distribus

Kategori

\begin{tabular}{lll}
\hline 1. & Pabrik & $\mathrm{C}$ \\
\hline 2. & Agen & $\mathrm{C}$ \\
\hline 3. & Pedagang A & $\mathrm{B}$ \\
\hline 4. & Pedagang B & $\mathrm{B}$ \\
\hline 5. & Pedagang C & $\mathrm{C}$ \\
\hline 6. & Pedagang D & $\mathrm{C}$ \\
\hline 7. & Pedagang E & $\mathrm{K}$ \\
\hline
\end{tabular}

Hygiene sanitasi sepanjang rantai distribusi es batu kristal di Surabaya sebanyak 2 tempat mendapatkan kategori baik $(28,57 \%), 4$ tempat KESIMPULAN

1) Kualitas mikrobiologi es batu kristal di sepanjang rantai distribusi di Surabaya parameter $E$. coli memenuhi syarat, sedangkan parameter MPN Coliform tidak memenuhi syarat;

2) Kualitas mikrobiologi es batu kristal di Pabrik positif mengandung MPN Coliform sebesar 10 koloni/100 $\mathrm{ml}$ sampel dan negatif $E$. coli, es batu kristal tidak memenuhi syarat mikrobiologi;

3) Kualitas mikrobiologi es batu kristal di agen es batu Pasar Atom positif mengandung MPN Coliform sebesar 12 - 15 koloni/100 ml sampel

\section{SARAN}

1. Bagi Dinas Kesehatan untuk melakukan pengawasan secara berkala.

2. Bagi pabrik membuat Standar Operasional Prosedur pengolahan bahan baku.

3. Bagi agen dan pedagang untuk meningkatkan hygiene sanitasi alat angkut, mendapatkan kategori cukup baik (57,14\%), dan 1 tempat mendapatkan kategori kurang baik $(14,29 \%)$.

dan negatif $E$. coli, es batu kristal tidak memenuhi syarat mikrobiologi;

4) Kualitas mikrobiologi es batu kristal di tingkat pedagang es minuman adalah tidak memenuhi syarat, negatif $E$. coli pada semua pedagang dan MPN Coliform berkisar 15 - 43 koloni/100 ml sampel; dan

5) Hygiene Sanitasi sepanjang rantai distribusi es batu kristal pada pedagang A dan B mendapatkan kategori baik; pada pabrik, agen, pedagang $C$, dan pedagang $D$ mendapatkan kategori cukup baik; dan pedagang $E$ mendapatkan kategori kurang baik.

tenaga pengangkut, peralatan, dan penjamah. 4) Bagi peneliti lain untuk melakukan penelitian dengan pemeriksaan kualitas fisik dan kimia. 


\section{DAFTAR PUSTAKA}

Departemen Kesehatan RI. 2002. Sanitasi Makanan dan Minuman pada Institusi Pendidikan Tenaga Sanitasi. Surabaya : 66

Departemen Kesehatan RI. 2004. Kumpulan Modul Kursus Hygiene Sanitasi Makanan \& Minuman. Surabaya : 65-66, 205-212

Departemen Kesehatan RI. 2006. Kumpulan Modul Kursus Hygiene Sanitasi Makanan \& Minuman. Jakarta

Eliyanti. 2014. Studi Tentang Bakteri Escherichia Coli Dan Logam Berat Dalam Es Batu Yang Digunakan Pedagang Di Sepanjang Pantai Purus Kota Padang. http://ejournals1.stkip-pgrisumbar.ac.id/index/geografi/article/view/28 70. 29 November 2015

Entjang, I. 2000. Sumur Gali dan Sarana Air Bersih yang Saniter. Alumni, Bandung.

Entjang, I. 2003. Mikrobiologi dan Parasitologi untuk Akademi Keperawatan dan Sekolah Tenaga Kesehatan yang Sederajat. Bandung: Citra Adtya Bakti.

Jay, James M. 2005. Modern Food Microbiology seventh edition. America. Springer Science + Business Media. Inc.
Keputusan Menteri Kesehatan Republik Indonesia. Persyaratan Hygiene Sanitasi Rumah Makan dan Restoran. Nomor: 1098/MENKES/SK/VII/2003. Depkes RI. Jakarta

Keputusan Menteri Kesehatan Republik Indonesia. Pedoman Persyaratan Hygiene Sanitasi Makanan Jajanan. Nomor: 942/MENKES/SK/VII/2003. Depkes RI. Jakarta

Natsir, Nur Alim, 2014. Analisis Kandungan MPN Coliform Fecal Pada Sumur Galian Dan Sumur Bor Di Rt 01 Desa Batu Merah Kecamatan Sirimau Kota Ambon. Jurnal Fikratuna. 6 : Nomor 1, Januari-Juni 2014

Peraturan Menteri Kesehatan Republik Indonesia. Persyaratan Kualitas Air Minum. No : 492/Menkes/Per/IV/2010. Depkes RI. Jakarta

Peraturan Menteri Perindustrian Republik Indonesia. Pedoman Cara Produksi Pangan Olahan yang Baik (Good Manufacturing Practices). Nomor: 75/M-IND/PER/7/2010. Depkes RI. Jakarta

Standar Nasional Indonesia. 1995. Es Batu. No: 01-3839-1995 